\title{
Turning Critique Inside Out: Foucault, Boltanski and Chiapello on the Tactical Displacement of Critique and Power
}

\section{Lars Thorup Larsen}

For citing, please use this reference to the final, published version:

Larsen, Lars Thorup(2011) 'Turning critique inside out: Foucault, Boltanski and Chiapello on the tactical displacement of critique and power', Distinktion: Scandinavian Journal of Social Theory, 12: 1, 37-55

The published version can be accessed through this link: http://www.tandfonline.com/doi/abs/10.1080/1600910X.2011.549334

\begin{abstract}
The relationship between critique and power is controversial in both society and sociology. Instead of setting a normative yardstick of critique, the article looks to conceptualize the intimate relationship between critique and power based on the observation that both are often displaced in processes of major social change, not least in the recent decades' reversal of hierarchy. The article conceptualizes the main idea about displacement of critique and power on the basis of what Foucault terms the 'tactical polyvalence of discourse' and similar ideas from the governmentality lectures. The argument is further developed in a discussion with Boltanski and Chiapello's work on the new spirit of capitalism. The discussion illustrates how effective critiques of power often turn the inside out of normative ideas about conduct or management, which is exemplified in the movement from anti-authoritarian critiques of hierarchy after 1968 to new and flexible forms of government.
\end{abstract}

Keywords: Boltanski; Chiapello; critique; displacement; Foucault; governmentality; power

\section{Introduction}

Hierarchies are not what they used to be. Hierarchical organizations, top-down regulation and other direct forms of exercising power have come under heavy fire across Western societies, and the critique has come from both left and right. This does not mean that hierarchies no longer exist, only that they have become increasingly difficult to legitimize as such. It is even hard for people today to imagine that organizational forms such as hierarchy and bureaucratic organization were not always understood in negative terms, but were once considered to be the highpoints of Western rationality. Although new types of hierarchies are continuously formed, it is nonetheless striking how many social transformations seem to stem from similar critiques of power. In political science, for example, the traditional focus on 'government' has seen some serious competition from rival concepts like 'networks' and 'governance' (Rhodes and Marsh, 1992; Rhodes, 1997). Normative discourses on power and democracy express a similar displacement in ideals, for example in notions such as deliberative democracy or governance from below. Also, neoliberal ideas about using market mechanisms in public governance build on the same critique of centralized power. 
If we look to specific empirical fields, we see similar transformations of the dominating ideas, especially in policy areas where citizens come into contact with traditional knowledge authorities such as teachers or doctors. Many education reforms shift the focus away from teaching and the teacher in order to make the student's own learning process the key priority. We have witnessed a comparable shift in health care, because the treatment-oriented paradigm based on the doctor's knowledge authority has been heavily criticized and supplanted by patient-centered strategies of health promotion and empowerment. Similar shifts from authority to the subject could easily be found in areas like labor market or environmental policy, but the key point is to observe what these diverse transformations have in common.

First, they all shift the spotlight away from authorities and those who exercise power in order to focus almost exclusively on the subject of power, i.e. the student, the patient or the employee. By relying on the same anti-authoritarian shift of perspective, these transformations all embody the same implicit critique of hierarchical power. Second, these transformations not only indicate parallel shifts in the structure of power relations, but also a series of developments in which critical ideas from the social sciences seem to have played a role in fueling criticism against existing power relations and in pointing towards alternatives. Critical ideas appear to have displaced the hierarchical power relations or at least played some role in the transformation since the new power relations often carry footprints of previous forms of critique.

The main objective of this article is to understand displacements of power and critique. Not in the sense that existing power relations are simply adapted to fit some fixed normative standard of critique, but rather that both power and critique are displaced in the process. The temporal aspect of these displacements is quite important because it is only over the course of time that one can observe what happens to critical ideas when they become effective and play a role in forming new power relations. As the title of the article indicates, when critical ideas are effective in displacing power relations, the ideas themselves are easily turned inside out in the same process.

The ambition to reflect on the displacements of power and critique does not mean that the article will put forward a general theory of power and critique. Not only would it be next to impossible to deliver such a grand result in one article, but setting the formulation of general theory as the main target could also easily shift the focus away from one of the other ambitions here, which is to show the interaction between critical social theory and power relations. In other words, if critical ideas in social theory appear to have played a role in some of these social transformations, then it would be presumptuous to assume that critique and power can be observed from a purely external point. We should rather make a virtue of the reflexivity of social theory and approach the discussion beginning with some of the existing literature on these transformations.

A number of works in contemporary social theory have put the critique of hierarchical power into a broader theoretical perspective and asked what major social changes are involved in the critique of authority. Several of these authors see the spread of new forms of organizing power largely as a response to the anti-authoritarian social critique in the aftermath of 1968. One of the major contributions here is Luc Boltanski and Ève Chiapello's Le nouvel esprit du capitalisme (2005), which demonstrates the tremendous effects of critique not only on the political development after 1968 , but also on the ideological underpinning of capitalism. Richard Sennett tells a similar story in his latest reflections on the New Culture of Capitalism (2006), which he believes originates in the New Left and its desire to replace the tyranny of institutions with flexible forms of community. History has fulfilled these desires, Sennett grants, but 
in a perverted form where increased flexibility has left people's working lives in an insecure and fragmented condition (2006: 2). The latter also resembles the new "precariousness" identified in contemporary French sociology as a consequence of the organizational fragmentation of the welfare state (Castel, 1999; Castel and Haroche, 2001; Lazzarato, 2007). In all of these analyses, we see a twofold transformation in the organization of power relations. Hierarchy is replaced by flexible, but also more subtle forms of control, while the individual citizen or the employee is deprived of the security previously guaranteed by the very same hierarchy.

Some scholars in the growing literature on governmentality have identified somewhat similar shifts where successful critiques of previous forms of government form the basis of new governmental rationalities. For example, Miller and Rose (1995) show how the critical demand for a 'humanization' of work ultimately led to a new and intensified form of governing the minute details of working life. Similarly, Foucault's own lectures demonstrate how the neoliberal critiques of the state often claim to govern as little as possible, but still develop ever more elaborate techniques to extract the most out of human capital.

It is tempting to just reject these as being 'perverse' examples of ideas like humanization being twisted to function as an instrument of power. However, this answer is highly unsatisfactory. Not only because there are few, if any, examples where successful critical ideas are adapted in a completely 'genuine' form, but moreover because it leaves unanswered the underlying theoretical question of how critique can be turned inside out. This article aims to approach this question, but without going though a long series of different conceptual understandings of critique. The idea is rather to clarify one very specific aspect of the social effects of critique, which is the process where a given organizational structure or set of power relations falls prey to critique and subsequently changes in order to accommodate or internalize it. Since few people would see these transformations as the termination of power altogether, the question is further to what extent there can be a repetitive series of displacements between power and critique.

By staying clear of the long historical account of critique, the scope of the main argument here also becomes more limited. Even though some of the theoretical arguments discussed below, not least from Foucault, refer to earlier periods, the key claim here about displacements of critique and power concerns social transformations since the 1960s as exemplified in the developments described by Boltanski, Sennett, and others. The article is also limited in the number of theoretical positions included, since the main argument about displacements of critique and power is developed through a comparative reading of Foucault and Boltanski and Chiapello respectively. Drawing on these authors, the article aims to conceptualize displacements of power and critique where the latter is somehow internalized into the former. Despite Foucault's well-known aversion against formulating 'theory', his writings do include some useful reflections on the transitivity of power relations, an aspect which has perhaps not received sufficient attention in the abundant scholarship on Foucault.

After Foucault's position, the second part of the article engages in a critical discussion with Boltanski and Chiapello's fascinating analysis of how anti-authoritarian ideas were transformed into the new spirit of capitalism. Their book constitutes one of the most comprehensive contributions on the displacement of critique, but until now their work has not been brought into a discussion with Foucault's work on the plasticity of power. Much more common is the juxtaposition between Boltanski's pragmatic approach and the structural streams of French sociology, not least represented in the work of Pierre Bourdieu, who is also Boltanski's preferred opponent (Boltanski, 2010: 
39-45; Bénatouïl, 1999; Silber, 2003). On the question of how critical ideas interacts with existing power relations, it is perhaps more fruitful to discuss how Boltanski and Chiapello's analysis compares with Foucault's perspective on power and governmentality, because they share an interest in the versatile functions of critical discourses. On the other hand, the idea is not to unite or even compare the two entire bodies of theory, but only to use the fault lines between their observations on the displacements of critique and power as a point of departure in order to better understand this complicated relationship; and since it is not an article about these authors per se, the discussion of displacement can draw on other authors and positions as well.

Before digging into Foucault, Boltanski and Chiapello, the next section seeks to clarify why it is not necessary or even fruitful to begin the discussion by formulating a social critique from an external position. Instead of trying to define the essence of critique or looking for a gold standard of normative critique, the objective is to observe sociologically what function critical discourses might have in social transformations.

\section{The Decline of Grand Critique}

It is not uncommon to find observers in critical theory mourning the decline of the grand critiques of society or at least discussing how social critique based on externally given universal values can be maintained (Browne, 2008; Honneth, 2000). Often, it is presented as if 'real' critique must necessarily build on an externally given normative foundation, which is not distorted by power or similar empirical phenomena. Some critical theorists, for exampe, fear that internal forms of critique will deflate into a poor version of 'criticism' if they fail to hang on to an external normative yardstick (Adorno cited in Browne, 2008: 8). Without blaming this on critical theory in general, it is fair to say that few places have this point of view been stated more clearly than in Habermas' The Philosophical Discourse of Modernity (1987). There, he poses the often-quoted rhetorical question: If power is unavoidable, as Foucault claims, "... why fight at all?" (Habermas, 1987: 284). Not only is it moral blackmail to present such a false ultimatum, but a more troubling aspect is that it appears to make normative foundations plausible simply by reducing the opposite to an absurd question. It is like saying that we cannot question objective truth without making science altogether pointless.

The decline of grand or radical critique should not necessarily be understood as a discussion about its foundation, because it also refers to a specific historical development. In Boltanski's and Sennett's diagnoses of the present mentioned above, the decline of radical critique does not concern its philosophical status, but stands as a testimony of the tremendous influence the critical ideas of the 1960s and 1970s have had on today's society. In other words, the decline of radical critique is somewhat linked to the successfulness of critique even though it appears to have lost the grandness of Marxist 'unmaskings' of domination, exploitation, etc. Although Boltanski and Chiapello maintain the possibility of performing a critique of society, the main ambition is to develop a 'sociology of critique', i.e. a descriptive, sociological analysis of critique in rather than of society (Boltanski and Chiapello, 2005: xii; Boltanski, 2010: 46).

A similar distinction between critique in or of society emerges if we accept $\mathrm{Ni}$ klas Luhmann's characterization of functional differentiation. Since modern society has been deprived of moral integration (1991: 85f), no external source of morality can grant legitimacy to the functional subsystems while each one regulates its own operations and basically legitimizes itself (Luhmann, 1990: 19). Instead, sociology may become the vehicle of self-description and establish a sort of quasi-external observation of society within society itself (Luhmann, 1994: 135f). Instead of critiques from a completely 
external point, critiques of society should be understood as part of their own object and therefore they have to reconcile with the condition of self-reference.

The condition of self-reference can of course be portrayed as a defeat for normative foundations because critique is no longer in a position to judge the totality of society, but self-reference is also what enables a greater reflexivity of critique. It is not the same, however, as employing a strict separation between facts and norms, only a question of what point critique is observed from. As it should be clear, this article aims to show the analytical advantages of an internal conception of critique and also to discuss the problems associated with using both internal and external perspectives at the same time like Browne (2008) as well as Boltanski and Chiapello (2005) do.

The next section attempts to decipher Foucault's understanding of this internal function of critique, which is a particular aspect of his general analytics of power as well as the literature on governmentality.

\section{Foucault on the Tactical Polyvalence of Critique}

In a well-known passage from La volonté de savoir, Foucault writes that the relationship between power relations and discourses on power is 'tactically polyvalent' (1976: 132), because the tactical function of critical discourses is both heterogeneous and unstable. Perhaps not the most intuitive expression, but it may be easier to appreciate the general applicability of this notion if we simply understand it as the constant possibility of tactical displacements. The point is that tactical displacements between power and resistance can alter the meaning of critical discourses dramatically, for example if the suppressed, or more generally the subjects of power, take over the means of power and formulate their own positive counter strategy. This idea was already implicit in Nietzsche's metaphorical tale of the 'slave revolt in morality' (1999), but Foucault expands the idea to the extent of becoming synonymous with his way of writing genealogy altogether.

He explains the tactical displacements of critique by referring to early-modern discourses on homosexuality. Although these juridical and scientific categories were clearly produced to contain homosexual behavior and preserve normality, they were later turned upside down when homosexuals began to speak of them selves in the very same terms (Foucault, 1976: 134). Another case of polyvalent discourses on power is where a number of discursive elements are united solely by their opposition towards a common enemy, and where the demise of the enemy can change this unity dramatically. This is exemplified in Slavoj Žižek's discussion of socialist groupings in Eastern Europe whose unity was secured by their resistance towards the capitalist class enemy in the West, but fragmented when the class enemy became a friend (2002: 148).

Since critical discourses are unstable depending on what they stand opposed to, Foucault suggests a power analysis that takes its methodological point of departure in different forms of resistance. Every power relation is accompanied by resistance and has an intimate relationship with it - at least on a discursive level - and the intimate space between power and resistance is precisely where the displacement of critique unfolds.

Foucault later recasts this point within the framework of governmentality studies, in particular through his 1978 lectures at the Collège de France. The overall idea is to study power as a way to govern that in itself embodies a reflection on how the subject governs him- or herself (Foucault, 2004a: 196f). In accordance with the focus on 
resistance and polyvalent critical discourses, Foucault then proceeds with his study by analyzing a series of revolts of conduct in both religious, ethical and political contexts.

For example, the Protestant Reformation was a revolt against the art of governing both spiritual and political matters in the Catholic Church (Foucault, 2004a: 199). The perspective is not only of a historical significance, however, because one should see cultural revolts like the Youth Rebellion of 1968 or the battle for gender equality as being similar internal revolts in the forms of conduct. It is a deliberate strategy to study conduct across such a broad spectrum, because moral revolts can be recycled and have tremendous consequences in an entirely different sector than where they originated (Foucault, 1994a: 226ff).

\section{Critique and Counter-conduct}

The phenomenon of critique is fundamentally linked to resistance for Foucault, although it is not entirely clear whether he understands critique and resistance as essentially the same thing. Critique is generally understood as being of a discursive nature while resistance can refer to both discursive practices as well as physical acts of resistance. Perhaps in an effort to avoid taking sides in this matter, Foucault talks more broadly of counter-conduct ('contre-conduites') (2004a: 199). There is, he claims, an "immediate and fundamental correlation between forms of conduct and counterconduct" (Foucault, 2004a: 199), although the word correlation is not used in its statistical sense here, but in the genealogical sense of familiarity. Any type of counter-conduct thus holds the promise of becoming a new form of conduct itself, and when you study governmental changes over time, it is possible to observe a series of displacements where the critics take power and establishes a new relation of power.

In a talk at the French Philosophical Society in 1978, Foucault elaborates on his concept of critique, which was later published under the title 'Qu'est-ce que la critique? [critique et Aufklärung] (1990; cf. also Foucault, 2008: 9-22). In this lecture on the concept of critique, Foucault again announces the broader history of governmentality from the government of conscience in ancient and religious documents to modern forms of private and public management. The new aspect revealed in this talk is that alongside the historical procedures for governing individuals there is a parallel history of critiques in which individuals thought about how not to let them selves be governed in a certain way (Foucault, 1990: 37).

Critique and resistance are thus not in complete opposition to power and government as such, but mainly they oppose the specific way in which individuals are being subjected to procedures of government. Accordingly, Foucault goes on to define critique as "the art of not letting oneself be governed in this way" (1990: 38; emphasis in original) and where this so-called way can refer to anything from moral or religion to political ideas. By associating critique so intimately with the act of governing, Foucault implicitly discards the idea that real critique must refer to external final principles. The quoted definition is almost a paraphrase on Kant's little text on Enlightenment, which says that man can only escape the state of minority by having the courage to let himself be governed by his own understanding without the guidance of another (Kant, 1991: 54; Foucault, 1990: 40). The connection between Kant and Foucault's own understanding of critique is further elaborated in the inaugural Collège de France lecture of 1983, where Foucault associates the concepts of critique and Enlightenment with the broader theme of parrhesia (truth-telling) (Foucault, 2008: 21-2). To be clear, however, 
Foucault does not rely on the Kantian concept of critique, but makes up his own definition on the basis of Kant's understanding of guidance and Enlightenment.

This is how the concept of critique comes in direct contact with the problematic of power instead of being placed in a completely external position. Contrary to the ambitions of an external critique of social order as such, what we see here is a profound resemblance between politics and critique, between power and resistance, or between conduct and counter-conduct. The loss of the external position does not mean that power becomes omnipotent or unbreakable, because all power relations are in principle open to tactical displacements. Critical discourses do not merely function as an ideological glaze on top of a fixated power differential, but rather they can function as the tactical instrument to enable a critical alternative to become a new form of power. Another advantage of highlighting the plasticity of power and critique is that we are able to move beyond the common understanding of who counts as the real critics of society.

\section{Liberalism as the Critique of Governmental Reason}

The process of looking beyond the usual list of social critics is very clear in Foucault's lectures on liberalism and neoliberalism, where he characterizes them as being profoundly critical forms of governmentality (Foucault, 2004b). They are just not critical of capitalist society in the way we are used to see on the left, but rather it is the welfare state and basically any type of central planning that becomes the object of liberalism's critical imperative (cf. Hayek, 1945). According to Foucault, the basic ethos of liberalism says that you "always govern too much" and should be understood as a "critique of governmental reason" (2004b: 14f). It claims that society would be better off if only the state would economize with its means of government and recognize that society and the market already has its own form of self-government far more efficient than anything the state could ever hope to achieve.

A classic example is when the French treasurer Colbert politely asked the commerce guild what he could for them and got the resounding answer "Laissez-nous faire!" (Foucault, 2004b: 22). Adam Smith later incorporated a similar idea into the image of 'the invisible hand' that will lead the market to reach the common good as long as the state does not subject it to even the most benevolent visible hand. On this point, Foucault makes a swaggering comparison between the liberal critique of the state and Kant's critique of pure reason. While Kant sets a limit on what man can know about the world as it is in itself, liberalism says there is a clear limit on what the state can know about society (Foucault, 2004b: 286). Thus, the liberal critique of the state is an epistemological critique, because it bases the principle of laissez faire on the state's lack of knowledge about society, which in most cases means either the economy or civil society. Hayek (1945) later continued this type of epistemological critique by arguing that the knowledge embedded in the price mechanism is fundamentally dispersed and therefore cannot properly be subsumed in scientific knowledge or political attempts at 'planning society'.

Some commentators have mistaken Foucault's characterization of liberalism as support for the neoliberal wave of the late 1970s, but his enthusiasm is only analytical (cf. also Osborne, 2003: 13). Neoliberalism perfectly illustrates his imperative to study ideas in their technical materialization rather than as an ideological glaze on top of a material base as we saw in the liberal critique of political government. Also, Foucault's analysis of the neoliberals allows him to reverse the normal understanding of who can call them selves the critics of society, which again illustrates how discourses can be 
tactically displaced. Finally, what we find in Foucault's reflections on Smith and other liberals is not an agreement with their worldview, but an observation of how critique functions in the context of liberal governmentality.

This leads back to the question about the social critics of 1968 , because although the neoliberals reacted against them, they also continued the anti-authoritarian critique of 1968 in a different direction. Even though Foucault is rarely associated directly with the emancipatory philosophies of these revolts, he says in a 1980 interview that only after the events of 1968 have phenomena like crime and sexuality been opened for problematization (1994b: 81). More important than the Youth Rebellion itself are its social and political implications. It was a critical and polyvalent revolt of conduct, which led to a general crisis of authority facilitating displacements ranging from feminism to neoliberalism and from health promotion to the flexible organization of work.

The key argument here is to underline the familiarity of various sets of antiauthoritarian ideas after 1968 that all share the imperative to replace hierarchic authority with an alternative form of organization or management. While not being identical in their substance and not sharing any agreement on normative principles, these critiques against hierarchical authority share a number qualities stemming from their common enemy and what is at least a partially shared genealogy. Instead of seeing critique as a yardstick - the 'difference between how men and things are and how they could be' (Adorno quoted in Browne, 2008: 5) - this theoretical view enables us to see the slippery displacement of critical discourses into new forms of governing.

The next sections move on to discuss possible points of contact between this Foucauldian view and the more recent analysis in Boltanski and Chiapello's work on the new spirit of capitalism (2005), where they analyze how the ideas of 1968 were turned upside down and absorbed into capitalist forms of management.

\section{How to Study Management and Conduct}

Boltanski and Chiapello do not set out to create a whole new theory of capitalism. Instead, they depart from a minimal Weberian definition of capitalism as the imperative to unlimited accumulation of capital by formally peaceful means (2005: 4), although Guilhot points out that this was in fact Weber's definition of capitalistic economic action, not of capitalism as such (Guilhot, 2000: 363). Boltanski and Chiapello combine a number of theoretical positions with both text analysis and historical accounts in order to approach their object from a multifaceted perspective. The main plot obviously draws on both Marx and Weber, but is combined with a pragmatic study of how actions are justified in relation to the management or conduct of private businesses. The latter part draws directly on the framework for mapping forms of justification previously developed by Boltanski and Thévenot in De la justification (2006; cf. also 1999).

The most interesting part of Boltanski and Chiapello's work in this context is the analysis of management discourses and the discussion of how the critique of 1968 has influenced the formation of the new spirit. The price of such influence seems to be that critique has been thwarted, outpaced, disarmed (Guilhot, 2000: 356), recycled (Latour, 2004: 231) and pacified (Chiapello, 2003: 162) in the process. In the final part, I will also discuss the book's main conclusion, which makes a general association between critique and capitalism. Less attention will be given to the specific formation of the project city and the extensive historical accounts of artistic critique, social critique, and the transformation of work. 
The analysis of management discourses from the 1960s to the $1990 \mathrm{~s}$ is both similar to and on other points quite different from Foucault's studies of governmentality. The main difference is that Boltanski and Chiapello seem to work in a more systematic fashion by constructing two parallel data sets with 60 central management texts from each period. The data is then subjected to both a qualitative and a relatively simple quantitative analysis of what regimes of justifications are most commonly used in the 1960s and 1990s correspondingly (Boltanski and Chiapello, 2005: 60). On the other side, Foucault's use of empirical texts is rather some sort of 'snowballing' tracking references from one document to the other and producing the kind of heterogeneous web of significations that typically constitute a genealogy (2001). Another related difference is that while the genealogical approach is specifically interested in tracking how power interacts with critique to produce change, Boltanski and Chiapello's text analysis provides a mapping of what ideas dominate at two specific points in time. In a sense, they show a series of still images rather than explain a development in motion. This is partly due to the underlying pragmatist framework from Boltanski and Thévenot, which seeks to classify ideas rather than analyze their involvement in processes of change (Boltanski and Thévenot, 1999: 364-6). Le nouvel esprit du capitalisme bears the same characteristic, because although the book provides a thick, historical description of the displacement of critical ideas and their incorporation into capitalism, the text analysis itself does not analyze the process of change.

The two approaches also share several key features. First, they both analyze texts about management or conduct, although while Boltanski and Chiapello limit their study to business literature, Foucault studies texts about the political management of society. The difference between ideas on business or politics sounds bigger than it really is, because in both cases we are looking at ideas with broader ambitions on behalf of society. Perhaps most directly exemplified in Foucault's lectures on neoliberalism, but Boltanski and Chiapello similarly show how seemingly limited management ideas may imply a broader social transformation.

Second, there is a striking resemblance in why they believe sociological study should look into such texts. Foucault as well as Boltanski and Chiapello study texts with a normative or prescriptive purpose, i.e. practical documents telling certain people what to do or what not to do. This is the descriptive approach to study critique in society as mentioned above (see also Boltanski, 2010: 23). Boltanski and Chiapello frame it as an interest in "... works of advice (...) concerning the conduct of business" (2005: 59), which means normative texts in the sense of giving directions for how individuals should act. The criterion is surprisingly close to Foucault's selection to base his genealogy on practical texts that are themselves the objects of a 'pratique'. It means that they were created in order to be read, learned, meditated, used, tested or in any case that they constitute an instrument for the conduct of everyday life (Foucault, 1984: 20f).

It is thus significant that Foucault, Boltanski and Chiapello all base their respective analyses on influential texts about the conduct of individuals in the postwar period, although not exactly the same documents. The next section looks closer at the substance of both these analyses, and how they conceptualize the relationship between critique and displacements of power.

\section{What is Legitimate or What Works?}

It is noteworthy that all the involved authors view the transformation of forms of conduct as one of the key arenas of social change in the past thirty years. Since neither of them 
analyze the transformations on the level of actual organizations or institutions, their claim is essentially about the changing ideas about conduct. This is where some of the criticism against Boltanski and Chiapello falls short, because it confuses their claim about ideas of conduct with actual conduct or even specific people such as when Lazzarato claims that Boltanski and Chiapello overestimate artistic critique because workers in the arts world are very poor (Lazzarato, 2007). Even if artists are in fact poor, it is misleading to judge the veracity of Boltanski and Chiapello's theory by such numbers, especially because the 'artistic critique' is not necessarily carried out by artists, but only designates a certain mode of critique.

In comparison, Foucault's lectures mainly discuss ideas on how the conduct of government should be amended from state hierarchy into market-like network structures of self-government, while Boltanski and Chiapello study a similar displacement in the managerial literature. Foucault also devotes more attention to connect the problematization of government and conduct with the crisis of the welfare state (cf. Donzelot, 1996) and he even claims that postwar governmentalities have become 'state phobic' (Foucault, 2004b: 77-8). Boltanski and Chiapello similarly address the underlying crisis behind the subsequent shift to a new spirit of capitalism, but they generally focus less on crisis and problematization. Foucault's interest in tactical displacements makes it imperative for him to analyze opposition and resistance, i.e. what a new idea claims to depart from. Boltanski and Chiapello, however, focus more on the ensuing set of new, affirmative managerial ideas about how to motivate individuals to engage positively in capitalist organizations (Boltanski and Chiapello, 2005: 8; cf. also Boltanski and Thévenot, 1999: 366).

One area of common ground between the two perspectives is that neither of them makes a clear cut between what is seen as being effective or legitimate forms of power, which is far from the strict separation of facts and norms in the work of Jürgen Habermas (1996). In both Boltanski and Chiapello's and Foucault's analyses, one often encounters a situation where a new, critical idea about conduct is adopted not necessarily because it is understood as being good or legitimate in a normative sense, but simply because it 'works'. The point here is not only whether practical implementation corrupts critical ideas, which may be the case, but mainly that the distinction between facts and norms, or between legitimate power and whatever 'works', often becomes blurred when critical ideas are successful. If, for example, hierarchy is replaced with dialogue not just because the latter is perhaps morally superior but because it works better, is that still a victory for dialogue-centered normative theories if the use of dialogue is only instrumental?

Neither of these authors defines in a precise sense what constitutes a legitimate exercise of power, although Boltanski and Thévenot perhaps come closer to doing so in their earlier work on regimes or 'worlds' of worth (2006; 1999). In Foucault's analytics of power, legitimacy is not a key concept, but several of his analyses do in fact examine which techniques have been applied historically in order for power to be accepted as legitimate. This is what generally falls under the category of subjectivation, a process in which the subject becomes the medium of his own subjection as it is coined in the renowned discussion of Jeremy Bentham's 'Panopticon' (Foucault, 1975: 228-64).

Moreover, Foucault's interest in the legitimation of power reflects the antiessentialist stance of his analytics of power. Precisely because power is not a thing in itself but simply a name for certain social relations, Foucault says the starting point of the analytic should be the 'non-necessity' of both power and the subject. With power not being necessary at the outset, the analysis should try to describe the techniques by which the subject is brought to accept power and view it as legitimate (Foucault, 1980: 
lecture of January 30). We find a similar idea in Volonté de savoir, where Foucault argues in yet another critique of the juridical conception of power that it is only able to understand the subject's acceptance of power as being either completely free or the result of pure force (1976: 113f). In general, the phenomenon of legitimacy is not foreign to Foucault's perspective, but his interest is clearly in the ambiguity of legitimate power rather than in creating a substantive definition of legitimacy.

Later in the studies of governmentality, we find an additional reflection on the ambiguity of legitimate power. Reflections on how individuals should be governed are and have more or less always been closely interlaced with instrumental concerns about what works. Not in the sense that normative ideas on governing are reduced to brutal instrumentality, but more accurately that the empirical association between the two sets of criteria is much more intimate than normative, political theory usually leads us to believe. It makes it harder to maintain a 'purely' normative perspective on power, but it is precisely this ambiguity that makes the arts of government so productive in social transformations according to Foucault.

There is a comparable aspect in Boltanski and Chiapello's analysis, although they analyze the ambiguity between normative and instrumental functions within the more limited framework of private capitalist management. They do not use these exact terms, neither does Foucault in fact, but it is nonetheless the same duality we find in their work, only given a slightly different expression due to their inspiration from the pragmatist strings of French sociology (Bénatouïl, 1999; Silber, 2003; Boltanski, 2010). The next section looks closer at some of the internal tensions created by this ambiguity in the critique of hierarchies. First, we should emphasize how productive the ambiguity between the instrumental and the normative really is. It facilitates a continuous displacement and flourishing of new problems of conduct, because the normative conceptions of conduct can be tied to new actors and situations over and over again. For example, Boltanski and Chiapello argue that the most important shift in the management literature between the 1960s and the 1990s concerns who to motivate (2005: 62). The essential problem in the 1960s was how to motivate managers (cadres), who were now professionals with no ownership of the business. At this point, good management was about how to create a hierarchy where the managers conduct them selves as leaders.

In the 1990s, the management problem expands considerably because what good is it that managers are motivated if none of the employees are? In this sense, the motivation problem multiplies step by step. The new period focuses on making managers able to motivate all the employees of the business, both because it is seen as being intrinsically better and because it simply works better. In both these processes described extensively by Boltanski and Chiapello, we see an incorporation of critical ideas into what effectively becomes a new affirmative 'spirit' designed to create enthusiasm among employees involved in the reproduction of capital.

In a separate article, Chiapello (2003) relates the new spirit of capitalism to a dual concept of ideology in which one part designates the traditional Marxian function of concealing the real forms of domination and the other is the function of cultural integration of shared values. The crucial point here is not the separation between the two ideological functions under capitalism, but the ability of the spirit of capitalism to transform the one into the other, which Chiapello terms the 'production of legitimacy' (2003: 164-5). Similar to Foucault's interest in what facilitates the acceptability of power, this approach enables us to observe these tricky shifts where one can hardly distinguish if a critical idea becomes influential because it simply works or because it is seen as intrinsically better. Despite the different theoretical backgrounds Foucault, Boltanski and Chiapello all seem to agree that critique is perhaps the most productive when the dis- 
tinction between what is and what could be becomes blurred. What this means in theoretical terms is that in displacements of power and critique, both of them are in fact displaced. Critique changes the existing power relations, but is itself changed during the course of the very same process. This was the case in the former example about the displacement of motivational problems from owners to managers and then subsequently from managers to all employees, but it is also very much the case in the continuous attacks on hierarchy.

\section{The Reversal of Hierarchy}

Boltanski and Chiapello directly calls the management discourse of the 1990s a reversal of hierarchies (2005: 71). One of the period's most celebrated management gurus, Peter F. Drucker who is also known from his writings on the knowledge society and knowledge economy, calls the reversal of hierarchy a 'Big Bang' in organization. To characterize the transformation as a Big Bang does not reveal much about the justifications, only that the transformation is immense. The source of justifications behind the tremendous reorganization should rather be found in the anti-authoritarian social critics of 1968, but this connection is similarly ambiguous (Boltanski and Chiapello, 2005: 84).

On the one hand, the network organization builds on anti-authoritarian demands for flexibility, participation and a job that fulfills existential goals like personal autonomy, creativity, authenticity, and emancipation (Boltanski and Chiapello, 2005: 326). Various concepts are also imported to regulate how one should associate with others in the business world. Another one of the management gurus of the 1990s, Rosabeth Moss Kanter, deliberately stresses the importance of using empathy in business situations, whereas Isabelle Orgogozo introduces a Habermasian concept of the ideal speech situation into the internal communication of the business (Boltanski and Chiapello, 2005: 458).

On the other hand, despite the obvious import of a whole catalogue of normative and ethical values into the business literature, it is underlined time and time again that these values are applied because they 'work better'. The advantage of the network lies in its ability to motivate all employees as well as the organization itself. Moss Kanter calls it 'When Giants Learn to Dance' understood as a dance that creates flexibility and mobilizes the entire organization (Boltanski and Chiapello, 2005: 71).

From a normative standpoint, it is not hard to imagine that this type of operationalization will easily undercut the normative starting point itself. If you use Habermasian discourse ethics in business negotiations because it creates a stronger commitment among participants to stand by the result, discourse ethics gets instrumentalized in the same act. This again undermines the very premise of the ideal speech situation, which is communicative rather than instrumental rationality. The brutal simplification of Habermasian discourse ethics clearly exemplifies how productive it is to mix normative with instrumental concerns, which is what characterizes the displacement of hierarchy into flexible forms of management. It appears that critical ideas can influence the exercise of power by associating the critique with instrumental concerns regarding what just 'works', although it may seem counter-intuitive from a normative standpoint that such a compromise with power should be necessary or even possible.

One possible reason is that any given form of critique needs to establish a new relation of power or a new governmental rationality in order to replace the existing configuration. Contrary to the normative theories measuring the distance between what is and what could be, Foucault, Boltanski and Chiapello all focus on the technical 
measures used to facilitate the displacement of critique. While Foucault examines this under the headlines of governmental technologies and technologies of the self, Boltanski and Chiapello analyze critical discourses in connection with the so-called circumventing of 'tests of status' designed to put the critique into practice (Boltanski and Chiapello, 2005: 499; see also 2002).

Another key point is that the subversion of hierarchy described by Boltanski and Chiapello is not a process that happens once and for all. It can rather be described as a continuous displacement of successive critiques into new problems of conduct or management, which brings us back to Foucault's concept of 'tactical polyvalence' (1976: 132). The concept not only demonstrates how it is possible to turn the inside out of anti-authoritarian ideas and normative theories, but it also tells us why it is necessary for effective critiques of power to reconcile with some form of instrumental relation of power. Necessity is perhaps too strong a word here, but at least it is difficult to imagine examples where a normative critique has been effective without somehow adjusting to practical or empirical concerns. Boltanski and Chiapello discuss a similar problematic regarding capitalism, and they argue that critique finds itself in a kind of Sisyphus position in relation to capitalism: Critique has much in common with and must remain close to the object of its critique, in this case capitalism, they argue, but of course at the danger of co-optation (Boltanski and Chiapello, 2005: 41).

Drawing on Michael Walzer, they go on to say that the tragic position of critique stems from the way normative references are inscribed into the empirical world. The only possibility for social critics to generate responses and be heard is by renouncing the completely external position and reconcile with their rootedness in the existing society (Walzer in Boltanski and Chiapello, 2005: 53 n84). Normative critics who wish to change the existing society are then left in a paradoxical situation, because the orientation towards making a change becomes instrumental and thereby compromises the strictly normative point of departure. Again, this points towards an intimate relationship between critique and the empirical context to which it attaches itself, be it power in the case of Foucault or capitalism in the work of Boltanski and Chiapello.

\section{Internal or External Critique}

The question is then where Boltanski and Chiapello place them selves in the dispute between internal and external forms of critique. Do they share Foucault's understanding of tactical displacements in which critique is turned inside out in order to become an affirmative form of power, or does their association with theories of capitalism involve some sort of Marxist commitment to remain external? As argued in the previous sections, the core of their analysis is in a sense about the slippery internalization and displacement of critique in the period after 1968. Boltanski and Chiapello actually explore the social history of this process in much more detail than Foucault, for instance by describing the trajectories of leftists entering the management of French business in the 1980s (Boltanski and Chiapello, 2005: 197). When the Socialists took over the Presidency in 1981, a similar infusion became possible into public administration, in particular through the education of civil servants at the elitist École Normale d'Administration. They even mention how experts in Foucauldian critique of power played an active role (Boltanski and Chiapello, 2005: 198). In examples such as these, we see several examples of tactical displacements, such as when the leftist critique of the state allegedly 'became neoliberal without knowing it' as Boltanski and Chiapello say (2005: 202). 
If we look besides the individual trajectories from social critique to the state apparatus and ask about the broader relation between power and critique, Boltanski and Chiapello's position is not quite as clear. On the one hand, they acknowledge that the internal displacement of ideas is what makes possible the tactical reorganization of critique, such as in the shifting discourses on management. They even say that the project city - understood as an organized set of justifications and critical 'tests' - acts as a "self-referential critical mechanism, internal to and immanent in the world that is in the process of coming into being, and must limit itself if it is to last" (Boltanski and Chiapello, 2005: 522f, emphasis in original). So here they characterize the critical mechanism as being internal and like Foucault they seem to view this characteristic as being both the possibility and limitation of critique. Possibility because it connects directly with mechanisms of power in the existing society, and limitation because it is not able to stand entirely on the outside without becoming redundant, i.e. without losing the empirical connection with what is being criticized.

It is worth noting that internal critical mechanisms are initially grounded in one regime of justification and therefore do not have the same critical function in other regimes. However, several regimes or 'worlds' can be combined to produce a critical difference (Boltanski and Thévenot, 1999: 373). For example, Boltanski and Thévenot demonstrate what kinds of critique the market regime can raise against the other regimes (2006: 261-9), and even where this type of critique involves the combination of several regimes, it never involves a privileged external position and should thus be characterized as internal critique. Boltanski and Chiapello similarly argue that "[c]ritique is not monolithic" (2005: 503), again because there are always differentials between various critical forces in play and not simply a global dichotomy between critique and capitalism.

On the other hand, a lot of other places in Le nouvel esprit du capitalisme it is less clear if it is the one or the other. Here, it tends to shift between where they see critique as being internal to the transformations of power and where they tacitly return to what looks like a dialectical conception of ideas and material basis. For one thing, the quoted concept of internal critical mechanism stand somewhat in contrast to the way they make the concept of critique operational on the basis of Hirschman's concept of 'voice' (Boltanski and Chiapello, 2005: 42). Although the concept of voice might be useful in other contexts, it is not at all clear how it catches the multifaceted functions of critique as analyzed in their book and discussed in this article. As exemplified in Foucault's analysis of liberalism, but not least in Boltanski and Thévenot's own work on critical tests, displacements of critique include, but are not at all limited to situations where human beings stand up and voice their concerns. Think of the many neoliberal governmental mechanisms of New Public Management implemented across Western welfare states the past few decades. Their critical function, for instance in limiting the influence of interest groups upon welfare expenditure, is precisely built on an organizational mechanism designed to replace some voice options with 'exit' functions. The main point here is not to replace the concept of critique with Hirschmann's entire vocabulary, but to underline again that social protesting on the left is only one example of what is in fact a relatively general problem of the displacement of power.

If we turn to Boltanski and Chiapello's main conclusion (2005: 485-92), the ambiguity about internal critique in their work only becomes all the more evident when capitalism suddenly reenters the scene as the insatiable and fundamentally unchangeable monster. Their general argument is that critique can only lead to changes in the spirit of capitalism, not in the functioning of capitalism itself, although they do mention exceptional cases of violent critique (Boltanski and Chiapello, 2005: 490). Compared to 
the plasticity of the displacements analyzed throughout the book, the conclusion seems to leave us with a rather stale dialectic between critique and capitalism. If we remember how they first refused to deduce the function of the new spirit from an essentialist conception of capitalist 'logic', it is a bit of a rough landing to suddenly be faced with a more or less undifferentiated concept of capitalism, which even appears to coincide with society as such.

The problem lies not only in how you understand the internal functioning of capitalism, but especially in how it appears to stand like a monolith, unaffected by other social phenomena. While Foucault criticized Marxist state theory of being an 'indigestible meal' (Foucault, 2004b; Lemke, 2007) - i.e. an over-simplified deductive category Boltanski and Chiapello's conclusion leaves capitalism in a very raw form. This is somewhat surprising given the stated ambition to overcome the inherent problems of a Marxist division of base and superstructure (Chiapello, 2003: 163).

The main problem here is not the conception of capitalism in itself, since this is not what the article is about, but how it limits our understanding of the displacements between critique and power. In the same step as Boltanski and Chiapello elevate capitalism to this high status, it seems to take on qualities that are not even specific to the economy, but perhaps rather characteristic of society as a whole. For example, Boltanski and Chiapello assert that it is the specific 'absurdity' of capitalism, which makes the moral dimension crucial in creating new grounds for enthusiasm and involvement. Seen from the perspective of governmentality, however, this is hardly specific to capitalism, since all major reforms in governmental rationalities face the question of how to shape the moral conduct of the subject. In other words, how do we know that the displacement from one spirit of capitalism to another is necessarily indicative of the dominant economic order rather than the mark of a broader governmental transformation? If we retain Luhmann's concept of functional differentiation, we could similarly ask if the capitalistic economic system is necessarily more insatiable than any other functional subsystem. Perhaps what Boltanski and Chiapello identify as the insatiable nature of capital accumulation is simply what characterizes any subsystem or new type of governmentality.

When Boltanski and Chiapello place capitalism as the underlying and constant logic of society, they also somewhat devalue their previous insights into the internal displacement of critique. Their view might fit a broader common sense perception of global capitalism as being very powerful, but it also gives the critique of capitalism the opportunity to present itself as being formulated from a more 'clean', external position. Either way, it seems inconsistent with the ambition to produce a descriptive sociology of critique. Even more disturbingly, it leads to a restricted analysis of the power of capitalism, because the ability of capitalism to internalize its critics is heavily restricted when capital accumulation stands solid as a rock. What is even the relevance of the long description of critique and subsequent displacements in the spirit of capitalism when at the end of the day the logic of capitalism returns to power and installs a dialectical division of reality? The essential point here, again, is not to deliver an alternative account of capitalist accumulation, only to underline that a sociological analysis of ideational displacements must remain open to change. Not only within a given set of ideas, but also in what existing social relation the ideas attach themselves to, such it capitalism, power or the state.

\section{Displacements of Power and Critique}


The purpose of this article has been to understand displacements of power and critique, if perhaps only in a few, preliminary theoretical steps. The key claim is that displacements of critique and power are intimately linked in the sense that it is difficult to imagine critical ideas reforming power without somehow being instrumentalized in the process. In consequence, it can be difficult to produce a substantial definition of critique, because one of its main functions is to be polyvalent and work as a catalyst for the plasticity of power relations. An intimate relationship between critique and power also means that in a given process of change, it may be difficult to separate the displacement of the former from the latter. As illustrated in the discussion between Foucault, Boltanski and Chiapello, critical ideas can become powerful and displace the existing configuration while critique becomes much more instrumental than it was at the normative starting point.

The argument is not that all social structures are always open to change, because neither critique nor power are causal mechanisms; but when social transformations or revolts of conduct actually occur, we can expect to see a demand so to speak for critique, but also a process whereby critique is domesticated into new practices of power and governing. This is exemplified in the development from hierarchical power to flexible forms of governing, because the flexibilization of contemporary organizations and power relations originates in both ethical and political critiques of hierarchy. What constitutes before and after in such a process of social transformation can be difficult to ascertain, because the content of ideas changes along the line. As part of the argument, the article has tried to emphasize the sociological value of this type of tactical polyvalence, which makes critique less distinctive in an absolute sense but all the more empirically sensitive.

The previous discussion draws an analogy between Foucault's analysis of governmentality and Boltanski and Chiapello's work on the new spirit of capitalism, but the analogy only goes so far. In part, the two perspectives are clearly rivals. Foucauldians would probably characterize the new spirit of capitalism as being a flexible shift in governmental rationalities rather than having anything particular to do with capitalism; on the contrary, others would argue that Foucault's perspective is too descriptive to produce effective critical analyses. Also, some of the contact points between new governmentalities and the new spirit of capitalism may be incidental rather than necessarily point to a shared theoretical insight into the displacements of critique. What is essential, at least, is not to confuse the familiarities between various sets of critical ideas with an underlying identity. Neoliberalism, the critics of 1968 and the proponents of state phobic flexible organizations, for example, are not members of the same movement, but their ideas have a partly shared genealogy, which makes it interesting to observe cross-cutting patterns of critique and power.

Even if both Foucault and Boltanski clearly acknowledge the historical specificity of their findings, they still use their perspective widely across time and space whether it is in tracing the long lines of the arts of government or it is in the broad classification of critique and justification. The generality of the perspectives thus comes with a built-in danger of making diffuse generalizations or drawing a general theory of critique from what is really a series of specific cases. While the broad perspectives allows us to avoid premature epochal generalizations sometimes found in diagnoses of the present, they have to be used and read with a strong empirical sensitivity to the variability that displacements of power and critique involve.

The conceptual understanding of displacement in this article is not built on solid empirical knowledge, but rather on observed similarities between several theoretical positions as well as between a series of social transformations described in existing 
well-established analyses. Although the previous discussion is more supportive of Foucault rather than Boltanski and Chiapello, the main point is really to use the similarity of some of their analyses to ask theoretical questions. We need to develop a better understanding of why so many critiques and subsequent breakdowns of hierarchy look alike across these multiple empirical contexts. The proposal here is to begin by looking at the internal displacements of critical ideas and their relationship with the transitivity of power relations. Instead of being disappointed every time some critical social theory is absorbed into the outside world and its content watered out in the process, perhaps these instances are exactly where we should direct our attention to understand the intimate power of critique.

Aside from developing theory, another ambition would be to better understand the historicity of displacements. Not simply in the sense of being moderate or cautious about the scope of the argument put forward here, but also in thinking outside the initial period where hierarchies have been torn down. It is worth devoting the final note here to Latour whose article 'Why Has Critique Run Out of Steam?' (2004) makes the brilliant observation that today, not only the critical ideas of '68 have been turned inside out. The same can now be said for various critical perspectives on "knowledge-slashpower", including both Foucault, Bourdieu and himself, whose forms of critique have now come full circle so to speak. Because the critique of power is now being used to support of anything from conspiracy theories to the 'brownlash' against the environment, Latour asks if we have "... behaved like mad scientists who have let out the virus of critique" (2004: 230-1). The point here is not to feel embarrassed at the possible misuse of these theories, since after all it only accentuates the reflexivity of critique. The key challenge here is not necessarily to go and look for a new and uncontaminated theory, but instead to ask what changes if we are now witnessing a stage where constructivism and not merely the critique of hierarchy is being turned inside out.

\section{References}

Bénatouïl, T. (1999) 'A Tale of Two Sociologies: The Critical and the Pragmatic Stance in Contemporary French Sociology', European Journal of Social Theory 2(3): 379-96. Boltanski, L. (2010) De la critique. Précis de sociologie de l'émancipation. Paris: Gallimard.

Boltanski, L. and E. Chiapello (1999) 'The Sociology of Critical Capacity', European Journal of Social Theory 2(3): 359-77.

Boltanski, L. and E. Chiapello (2002) 'The New Spirit of Capitalism'. Paper presented to the Conference of Europeanists, Chicago, March 14-16 2002.

Boltanski, L. and E. Chiapello (2005) The New Spirit of Capitalism. London: Verso.

Boltanski, L. and L. Thévenot (2006) On Justification. Economies of Worth. Princeton:

Princeton University Press.

Browne, C. (2008) 'The End of Immanent Critique?', European Journal of Social Theory 11(1): 5-24.

Castel, R. (1999) Les Métamorphoses de la question sociale. Une cronique du salariat. Paris: Gallimard.

Castel, R. and C. Haroche (2001) Propriété privée, propriété sociale, propriété de soi. Entretiens sur la construction de l'individu moderne. Paris: Fayard. 
Chiapello, E (2003) 'Reconciling the Two Principal Meanings of the Notion of Ideology: The Example of the Concept of the "Spirit of Capitalism"', European Journal of Social Theory 6(2): 155-71.

Donzelot, J. (1996) 'L'avénir du social', Esprit 219: 58-81.

Foucault, M. (1975) Surveiller et punir. Naissance de la prison. Paris: Gallimard.

Foucault, M. (1976) Histoire de la sexualité 1: la volonté de savoir. Paris: Gallimard.

Foucault, M. (1980) Du gouvernement des vivants. Unpublished lectures at Collège de France 1980, accessible at Centre Michel Foucault, Bibliothèque IMEC, Paris.

Foucault, M. (1984) Histoire de la sexualité II: L'usage des plaisirs. Paris: Gallimard.

Foucault, M. (1990) 'Qu'est-ce que la critique? [critique et Aufklärung]', Bulletin de la Société française de Philosophie 84(2): 35-63.

Foucault, M. (1994a) 'Le sujet et le pouvoir', pp. 222-243 in Dits et Écrits IV 1980-1988.

Paris: Gallimard.

Foucault, M. (1994b) 'Entretien avec Michel Foucault', pp. 41-95 in Dits et Écrits IV 1980-1988. Paris: Gallimard.

Foucault, M. (2001) 'Nietzsche, la généalogie, l'histoire', pp. 1004-1024 in Dits et écrits I, 1954-1975. Paris: Gallimard/Quarto.

Foucault, M. (2004a) Sécurité, territoire, population. Cours au Collège de France 197778. Paris: Seuil/Gallimard.

Foucault, M. (2004b) Naissance de la biopolitique. Cours au Collège de France 197879. Paris: Seuil/Gallimard.

Foucault, M. (2008) Le gouvernement de soi et des autres. Cours au Collège de France 1982-1983. Paris: Seuil/Gallimard.

Guilhot, N. (2000) 'Review Essay', European Journal of Social Theory 3(3): 355-64. Habermas, J. (1987) The Philosophical Discourse of Modernity. Cambridge: Polity

Press.

Habermas, J. (1996) Between Facts and Norms. Cambridge: Polity Press.

Hayek, F.A.v. (1945) 'The Use of Knowledge in Society', The American Economic Review 35(4): 519-30.

Honneth, A. (2000) 'The Possibility of a Disclosing Critique of Society: The Dialectic of Enlightenment in Light of Current Debates in Social Criticism', Constellations 7(1): 11627.

Kant, I. (1991) 'An Answer to the Question: "What is Enlightenment?"', pp. 54-60 in Political Writings. Cambridge: Cambridge University Press.

Lazzarato, M. (2007) 'Les malheurs de la "critique artiste" et de l'emploi culturel', Transform 1 (http://transform.eipcp.net/transversal/0207/lazzarato/fr - URL consulted November 2010).

Latour, B. (2004) 'Why Has Critique Run Out of Steam? From Matters of Fact to Matters of Concern', Critical Inquiry 30: 225-48.

Lemke, T. (2007) 'An indigestible meal? Foucault, governmentality and state theory', Distinktion 15: 43-64.

Luhmann, N. (1990) 'The Representation of Society Within Society', pp. 11-19 in Political Theory in the Welfare State. Berlin: de Gruyter.

Luhmann, N. (1991) 'Paradigm Lost: On the Ethical Reflection of Morality: Speech on the Occasion of the Award of the Hegel Prize 1988', Thesis Eleven 29(1): 82-94.

Luhmann, N. (1994) "'What is the Case?" and "What Lies behind It?" The Two Sociologies and the Theory of Society', Sociological Theory 12(2): 126-139.

Miller, P. and N. Rose (1995) 'Production, identity, and democracy', Theory and Society 24: 427-67. 
Nietzsche, F. (1999) On the Genealogy of Morals: A Polemic. Oxford: Oxford University Press.

Osborne, T. (2003) 'What is a problem?', History of the Human Sciences 16(4): 1-17. Rhodes, R.A.W. and D. Marsh (1992) 'New directions in the study of policy networks', European Journal of Political Research 21(1-2): 181-205.

Rhodes, R.A.W. (1997) Understanding Governance: Policy Networks, Governance, Reflexivity and Accountability. Buckingham: Open University Press.

Sennett, R. (2006) The Culture of the New Capitalism. New Haven: Yale University Press.

Silber, I. F. (2003) 'Pragmatic Sociology as Cultural Sociology: Beyond Repertoire Theory?', European Journal of Social Theory 6(4): 427-49.

Žižek, S. (2002) Welcome to the Desert of the Real. London: Verso.

Lars Thorup Larsen, $\mathrm{PhD}$, is Postdoctoral researcher at the Department of Political Science, Aarhus University. He has worked on several topics in social and political theory as well as research on public health policy, tobacco control, morality politics and the sociology of professions. Recent articles have appeared in Critical Discourse Studies, Science and Public Policy and the Austrian Journal of Political Science.

Lars Thorup Larsen

Department of Political Science

Aarhus University

DK- 8000 Aarhus C

Denmark

Tel: +4589421316

Email: lars@ps.au.dk 